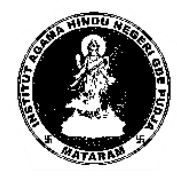

\title{
STRATEGI PENCAPAIAN PERKEMBANGAN ANAK DI TAMAN KANAK-KANAK DWIJENDRA MATARAM
}

\author{
I Wayan Rudiarta a, I Gusti Ayu Sukerti b, Ni Putu Chandra Paramis Suary c \\ abcInstitut Agama Hindu Negeri Gde Pudja Mataram \\ aiwayanrudiarta@iahn-gdepudja.ac.id, bgustiayukety@gmail.com, \\ ccndraswary@gmail.com
}

(Diterima: 10 Januari 2022; Direvisi: 17 Januari 2022; Diterbitkan: 31 Januari 2022)

This work is licensed under a Creative Commons Attribution-ShareAlike 4.0 International License

\begin{tabular}{l}
\hline Keywords: \\
\hline Strategy, \\
Development, \\
Child, \\
Kindergarten
\end{tabular}

This study aims to describe the strategies used in efforts to achieve child development that took place at TK Dwijendra Mataram. The development of children who are the subject of research includes aspects of religious and moral values, physical-motor, cognitive, language, socio-emotional and artistic. Preschool age is a golden age for the growth and development of children. At this golden age, a child must be given the right touch to reach the point of maximum development. This research was conducted using a qualitative approach in which the data obtained will be processed and then described in the form of words that describe the results of the study. To test the validity of the data, a triangulation technique was used. To obtain the data was used the methods of interview, observation, and literature study. The results of the study indicate that to achieve the development of religious and moral values, a habituation strategy is used, namely habituation to cultivate a religious and moral culture. Furthermore, on the physical-motor aspect, the teacher uses interactive learning strategies and participatory learning. In the cognitive aspect, the teacher uses a reward strategy, singing method, and a Student Center Learning approach. In the language aspect, teachers use mentoring strategies to students to the fullest. Then on the aspect of socio-emotional development, the strategy applied is the fascinating storytelling method. As for the development of the artistic aspect, the school holds extra-curricular activities. 
Kata kunci:

\begin{tabular}{l}
\hline Strategi, \\
Perkembangan, \\
Anak, Taman \\
Kanak-Kanak.
\end{tabular}

\section{PENDAHULUAN}

Segala lini kehidupan selalu menempatkan pendidikan sebagai pondasi utama. Pendidikan yang baik akan memberikan implikasi yang baik pula pada berbagai aspek kehidupan yang lain, mencakup aspek sosial, ekonomi, politik maupun hukum. Hal ini tentunya menjadi sebuah keniscayaan apabila ada yang
Abstrak

Penelitian ini bertujuan untuk memaparkan strategi yang digunakan dalam upaya pencapaian perkembangan anak yang berlangsung di TK Dwijendra Mataram. Perkembangan anak yang menjadi subjek penelitian mencakup aspek nilai agama dan moral, fisik-motorik, kognitif, Bahasa, sosialemosional dan seni. Usia prasekolah adalah usia emas bagi pertumbuhan dan perkembangan anak. Pada usia emas ini seorang anak harus diberikan sentuhan yang tepat guna mencapai titik perkembangan maksimal. Penelitian ini dilakukan dengan menggunakan pendekatan kualitatif yang mana data yang diperoleh akan diolah dan kemudian dideskripsikan dalam bentuk kata-kata yang menggambarkan hasil penelitian. Untuk uji keabsahan data, digunakan triangulasi teknik, dengan pengumpula data menggunakan teknik wawancara, observasi dan studi kepustakaan. Hasil penelitian menunjukkan bahwa untuk pencapaian perkembangan nilai agama dan moral digunakan strategi pembiasaan, yaitu pembiasaan untuk menumbuhkan budaya beragama dan bermoral. Selanjutnya pada aspek fisik-motorik guru menggunakan strategi interaktif learning dan pastisipatif learning. Pada aspek kognitif, guru menggunakan strategi pemberian Reward, metode bernyanyi dan pendekatan Student Center Learning. Pada aspek Bahasa, guru menggunakan strategi pendampingan kepada siswa secara maksimal. Kemudian pada aspek perkembangan sosialemosional, strategi yang diterapkan adalah dengan metode bercerita yang memukau. Sedangkan untuk pengembangan aspek seni, sekolah mengadakan kegiatan ekstra kurikuler secara rutin. mengadakan bahwa masa depan sebuah bangsa terletak pada kualitas pendidikannya. Pendidikan yang berkualitas akan menuntun tercapainya peradaban bangsa yang berkualitas.

Secara umum pendidikan mencakup tiga jalur, yaitu pendidikan informal yang disebut sebagai pendidikan pertama dan utama yang 
berlangsung di lingkungan keluarga, pendidikan formal yang berlangsung di sebuah instansi pendidikan, dan pendidikan non formal yang berlangsung di masyarakat. Dari tiga jalur pendidikan tersebut, pendidikan formal mendapat perhatian tersendiri, karena memiliki indikator keberhasilan yang dapat diukur secara kuantitatif. Pendidikan formal ini berlangsung pada berbagai jenjang, dimulai dari Pendidikan Anak Usia Dini (PAUD), Sekolah Dasar (SD), Sekolah Menengah Pertama (SMP), Sekolah Menengah Atas (SMA)/ Sekolah Menengah Kejuruan (SMK) hingga pada jenjang Perguruan Tinggi (PT).

Pendidikan pada jenjang PAUD merupakan jenjang pendidikan yang menjadi usia emas (golden age) bagi perkembangan seorang anak (Rozalena \& Kristiawan, 2017). Hal ini sejalan dengan filosofi klasik masyarakat Bali yang sering menyebutkan bahwa masa anak-anak seperti filosofi Ilalang (Petapan Ambengan), semakin muda semakin tajam. Hal ini bermakna bahwa anakanak pada usia emas akan dengan sangat baik mampu menerima pendidikan, dan pada usia ini juga seorang anak bisa dibentuk sesuai bakat dan potensi yang dimiliki. Pendidikan juga harus menghadirkan situasi "DEMEN" pada siswa, yaitu:

(1) Datang ke sekolah dengan bahagia;

(2) Edukasi sesuai kebutuhan siswa; (3) Memberikan pengalaman baru; (4) Estimasi waktu belajar tidak terbatas; dan (5) Nuansa kekeluargaan sangat terasa (Rudiarta, 2021). Situasi ini harus dihadirkan pada pembelajaran PAUD, sehingga arah dan tujuan pendidikan dapat tercapai.

Pendidikan PAUD sangat berimplikasi pada pertumbuhan dan perkembangan seorang anak. Pertumbuhan anak berkaitan dengan adanya perubahan pada ukuran pada fisik anak yang bisa terlihat dengan jelas, sedangkan perkembangan merupakan hasil interaksi kematangan susunan saraf dan organ yang terjadi secara simultan dengan pertumbuhan (Chamidah, 2009). Melalui pendidikan PAUD, seorang anak akan didampingi oleh guru untuk dapat tumbuh dan berkembang dengan baik. Mengacu pada Mendikbud Nomor 137 Tahun 2014 Tentang Standar Nasional Pendidikan Anak Usia Dini pada pasal 7 disebutkan bahwa yang dimaksud pertumbuhan adalah mencakup penambahan berat badan dan tinggi badan sesuai dengan standar kesehatan dan standar gizi yang telah ditetapkan. Sedangkan yang dimaksud dengan perkembangan mencakup enam aspek seperti aspek nilai agama dan moral, aspek fisikmotorik, aspek kognitif, aspek Bahasa, aspek sosial-emosional, dan aspek seni.

Dalam hal pertumbuhan anak, sekolah tidak akan berperan maksimal, hal ini dikarenakan pertumbuhan dipengaruhi faktor genetika, suplai makanan dan pemenuhan gizi si anak. Akan tetapi untuk perkembangan anak, sekolah dalam hal ini PAUD memiliki peran yang sangat penting. 
Dalam bentuk formal, PAUD juga bisa berbentuk Taman Kanak-Kanak (TK) (Rozalena \& Kristiawan, 2017). Dan salah satu TK yang ada di kota mataram dengan karakter Hindu yang cukup kental adalah TK Dwijendra Mataram.

Pada Tahun Ajaran 2021/2022, secara keseluruhan TK Dwijendra Mataram memiliki 40 orang siswa yang terbagi menjadi kelas A (Usia 4-5 Tahun), Kelas B1 (Usia 5-6 Tahun) dan Kelas B2 (Usia di atas 6 Tahun). Pembelajaran di TK Dwijendra Mataram masih menggunakan Kurikulum 2013, dan berdasarkan hasil observasi yang peneliti lakukan terlihat secara aktif para guru selalu memperhatikan aspek perkembangan para siswa.

Penelitian dari Dahlia Patiung dkk yang berjudul "Deteksi Dini Pencapaian Perkembangan Anak Usia 3-4 Tahun Berdasarkan Standar Nasional Pendidikan Anak Usia Dini" menunjukkan bahwa subjek penelitian yang berjumlah tiga orang mengalami perkembangan yang sangat baik pada keenam aspek perkembangan (nilai agama dan moral, fisik-motorik, kognitif, Bahasa, sosial-emosional, dan seni) yang tiada lain disebabkan adanya pola asuh yang tepat dari orang tua dan pemberian stimulus yang tepat pada semua aspek perkembangan disamping didukung oleh motivasi dari orang sekitar lingkungan (Patiung et al., 2019).

Pola asuh dan stimulus yang tepat menjadi kunci penting dalam upaya mencapai perkembangan anak secara optimal. Dalam pendidikan di TK, guru memainkan peran dalam pencapaian perkembangan anak. Pola asuh atau pembelajaran dan stimulus harus disesuikan dengan kebutuhan anak. Hal ini mengindikasikan bahwa guru harus menerapkan strategi yang tepat guna mencapai permbangan anak. Berdasarkan hal tersebut, melalui penelitian ini peneliti akan membahas strategi guru dalam pencapaian perkembangan anak di TK Dwijendra Mataram, yang bertujuan untuk mendeskripsikan proses pembelajaran yang berlangsung dalam upaya mencapai tujuan pendidikan PAUD mengacu pada Standar Nasional PAUD.

\section{METODE}

Penelitian ini dilakukan di TK Dwijendra Mataram yang merupakan salah satu TK bernuansa Hindu yang ada di kota Mataram. Penelitian ini menggunakan pendekatan kualitatif yang mana data yang diperoleh melalui teknik observasi, wawancara dan studi kepustakaan yang kemudian dianalisis dan dideskripsikan.

Peneliti menjadi instrumen utama dalam penelitian ini, kedalaman kajian yang dilakukan disesuaikan dengan kemampuan analisis dan wawasan peneliti. Untuk menguji keabsahan data, peneliti menggunakan triangulasi teknik, yaitu memadukan data penelitian yang diperoleh melalui observasi, hasil wawancara dan juga studi kepustakaan yang dilakukan. 


\section{PEMBAHASAN}

Perkembangan anak merupakan hal yang perlu mendapat perhatian semua pihak, mengingat anak-anak adalah generasi yang akan meneruskan eksistensi peradaban manusia. Perkembangan anak pada usia Prasekolah menjadi hal yang penting, jangan sampai tanda bahaya yang dapat mempengaruhi tercapainya perkembangan anak diabaikan atau justru tidak mendapatkan respons. Disinilah peran pendidikan Prasekolah seperti PAUD atau TK, pendampingan secara optimal dalam upaya mencapai perkembangan anak dapat dilakukan. Pada TK Dwijendra Mataram, aspek perkembangan anak selalu mendapatkan perhatian serius dari seluruh stakeholder, terhusus para pengajar (guru). Dalam upaya mencapai perkembangan anak secara optimal guru menggunakan strategi yang terjabarkan sebagai berikut.

\section{a. Perkembangan Nilai Agama dan} Moral.

Agama merupakan penuntun kehidupan manusia dalam keseharian sehingga menjadi terarah (Isnaini, 2014). Agama akan menjadi penuntun insan manusia dalam melakukan berbagai tindakan sehari-hari. Pengamalan ajaran agama secara baik akan melahirkan perilaku yang dilandasi moral. Moral itu sendiri merupakan serangkaian nilai-nilai yang didalamnya memuat kaidah, norma dan aturan berperilaku yang baik yang merujuk pada karakter (Wadu \& Jaisa, 2017). Anak yang mampu mengembangkan nilai agama dan moral pada dirinya akan memiliki sebuah modal penting untuk pengembangan diri pada aspek lain.

Mengacu pada Mendikbud tentang SN-PAUD, disebutkan tingkat pencapaian perkembangan anak pada usia 4-5 Tahun sebagai berikut: (1) tahu agama yang dianut; (2) meniru cara beribadah dengan benar; (3) mengucapkan doa sebelum/sesudah berkegiatan; (4) mengenal prilaku yang baik/salah; (5) membiasakan diri berbuat baik; dan (6) mengucapkan/membalas salam. Sedangkan pada usia 5-6 Tahun terwujud dalam prilaku: (1) mengenal agama yang dianut; (2) beribadah; (3) berprilaku jujur, sopan, tolongmenolong dan punya rasa hormat; (4) menjaga kebersihan; (5) mengetahui hari raya (hari besar) agamanya; dan (6) punya sikap toleransi beragama (Mendikbud, 2014).

TK Dwijendra Mataram, sebagai TK yang bernuansa Hindu selalu menanamkan nilai-nilai keagamaan pada siswa. Ni Wayan Sucitra, Kepala Sekolah TK Dwijendra Mataram menyampaikan bahwa, dalam proses pembelajaran di TK, para siswa diajarkan Praktek Metanding Canang, diajarkan warna ista dewata. Para siswa juga selalu diajak berdoa sebelum/sesudah berkegiatan seperti pada saat makan, sebelum memulai pelajaran, termasuk pada saat akan pulang. Untuk menanamkan pemahaman agama yang lebih utuh, TK Dwijendra Mataram memiliki kebijakan bahwa siswa diwajibkan 
memakai pakaian Sembahyang setiap hari suci Purnama-Tilem. Disamping itu, bagi siswa yang baru bergabung di TK akan dilakukan upacara Upanayana, dan ketika sudah lulus akan melewati upacara Samawartana.

Ada tiga indikator yang bisa dijadikan tolok ukur tercapainya perkembangan anak pada nilai agama dan moral, yaitu: (1) mampu mengetahui adanya perilaku yang saling berlawanan, seperti benar-salah, baik-buruk, dan lain sebagainya; (2) mampu mengetahui makna sebuah kasih sayang terhadap makhluk ciptaan Tuhan; dan (3) mampu menirukan pelantunan doa (Patiung et al., 2019).

Strategi pencapaian perkembangan nilai agama dan moral yang dilakukan oleh guru di TK Dwijendra Mataram lebih merujuk pada pembiasaan bagi para siswa. Sedari dini para siswa dibiasakan sehingga akan terbudaya perilaku yang diharapkan. Awalnya memang siswa akan terpaksa, namun lamalama akan terbiasa hingga mencapai fase membudaya (Rudiarta, 2021). Dengan strategi ini, siswa TK Dwijendra Mataram mampu mencapai perkembangan pada aspek Nilai Agama dan Moral. Dengan pengembangan nilai agama, akan tumbuh sikap kebertuhanan pada anak yang berimplikasi pada penumbuhan karakternya (Rudiarta, 2021). Memang pencapaian pada setiap anak berbeda-beda tetapi dengan pembiasaan tadi, anak yang tingkat perkembangannya paling rendahpun sudah mampu mengenal agama dan perilaku bermoral-tidak bermoral.

\section{b. Perkembangan Fisik-Motorik}

Apabila perkembangan nilai agama dan moral lebih dipandang sebagai perkembangan psikis insani, pada perkembangan fisik-motorik lebih menonjolkan aspek yang bisa dilihat secara langsung. Perkembangan fisik-motorik terbagi menjadi tiga perkembangan, yaitu motorik kasar, motorik halus, kesehatan dan perilaku keselamatan. Pada pemahaman awal, perkembangan motorik anak dapat dicapai melalui berbagai stimulasi kepada anak seperti memberikan kesempatan bermain dan kebebasan untuk berkreasi (Sulaiman et al., 2019).

Perkembangan motorik kasar pada anak biasanya ditandai dengan mampunya anak melakukan gerakan tubuh secara terkoordinasi, baik dalam bermain maupun menjaga kebersihan diri. Ni Wayan Sucitra menuturkan, dalam mencapai perkembangan motorik kasar pada anak TK menyediakan arena bermain yang juga ditunjang dengan berbagai Alat Permainan Edukatif (APE) yang disesuaikan dengan tema pembelajaran. Dalam upaya pengembangan motorik kasar siswa, strategi pembelajaran interaktif menjadi kunci yang penting. Interaktif berkaitan dengan interaksi antara siswa dengan temannya, siswa dengan guru, maupun siswa dengan lingkungannya (Sriwahyuni et al., 2017). 
Perkembangan motorik kasar, terindikasi melalui kemampuan fisikal pada diri siswa. Berbeda halnya dengan perkembangan motorik halus yang berkaitan dengan penumbuhan daya kreativitas dan inovasi pada anak seperti membuat garis, lingkaran, menggambar, menggunakan alat tulis, dan lainnya (Mendikbud, 2014). Ni Luh Putu Tirtawati, salah satu guru kelas di TK Dwijendra menuturkan bahwa dalam melatih motorik halus anak, di TK sering diberikan pelajaran menggambar dan mewarnai. Diawali dengan mengajarkan siswa cara memegang pensil, kemudian siswa diberikan kebebasan mengekspresikan diri melalui media kertas yang dibagikan. Cara lain yang digunakan untuk mengembangkan motorik halus anak secara optimal adalah dengan memberikan permainan puzzle, yaitu anak menyusun potong-potongan puzzle menjadi sebuah gambar yang sesuai (Susanti \& Trianingsih, 2017). Dalam upaya mengembangan motorik halus metode kolase juga merupakan metode yang efektif, yaitu mirib dengan permainan puzzle, siswa menempelkan potongan kertas sesuai pola gambar (Suseni et al., 2021). Bersesuaian dengan itu, dalam upaya pencapaian motorik halus siswa, guru menerapkan strategi pembelajaran partisipasi, yang mana guru selalu mendampingi siswa dalam proses pembelajaran yang dijalankan. Karena dibutuhkan partisipasi penuh inilah di TK Dwijendra Mataram selalu memerlukan peran guru pendamping dalam pembelajaran di kelas.
Perkembangan kesehatan dan perilaku keselamatan pada anak juga mendapat perhatian penting selain perkembangan motorik kasar dan motorik halus. Perkembangan kesehatan mencakup berat badan, tinggi badan dan lingkar kepala. Sedangkan perilaku keselamatan mencakup berbagai antisipasi dini terkait keselamatan seperti mengunakan toilet, mengenal rambu lalu lintas, dan mengenal berbagai kebiasaan buruk bagi kesehatan. Di TK Dwijendra Mataram, guna mencapai perkembangan ini guru selalu melakukan komunikasi dengan orang tua siswa pada saat siswa dijemput. Guru akan menceritakan secara sekilas bagaimana perkembangan yang dialami anak, sehingga orang tua bisa memberikan stimulus yang yang tepat guna lebih merangsang perkembangan anak. Hal ini termasuk juga dengan perihal kesehatan dan perilaku keselamatan siswa.

\section{c. Perkembangan Kognitif}

Tingkat perkembangan motorik kasar memiliki pengaruh yang signifikan terhadap perkembangan kognitif anak (Solihin RDM, Anwar Faisal, 2013). Kognitif merupakan aspek perkembangan yang mencakup kemampuan dan aktivitas mental yang berkaitan dengan cara menganalisis informasi melalui proses berpikir dan Problem solving (pemecahan masalah) (Khiyarusoleh, 2016).

Dalam pembelajaran anak PAUD/TK, perkembangan kognitif mencakup beberapa hal yaitu belajar dan pemecahan masalah, berpikir 
logis, dan berpikir simbolik. Pada tahap belajar dan pemecahan masalah, hal yang dipelajari anak mencakup mengenal benda berdasarkan fungsinya, menggunakan bendabenda untuk bermain, mengkreasikan sesuatu sesuai dengan idenya, memecahkan masalah sederhana, menerapkan pengetahuan yang dimiliki dan bersikap kreatif (Mendikbud, 2014). Dalam kegiatan belajar dan pemecahan masalah, daya kritis dari anak akan semakin muncul ketika selalu diberikan sebuah reward apabila mampu melakukan/ mempelajari sesuatu dengan baik.

Pada perkembangan berpikir logis anak, ditandai dengan kemampuan anak memilah/ mengklasifikasikan suatu benda, keadaan, ataupun kegiatan yang dirasa masuk akal dan bisa diterima. Ketika anak sudah mencapai tahap perkembangan ini, rasa ingin tahu anak akan semakin meningkat. Pada tahap perkembangan ini, anak sudah mampu mengenal gejala sebab-akibat, sudah mampu mengklasifikasikan benda berdasarkan perbedaan warna, bentuk dan ukuran, serta mulai mengenai berbagai pola (Mendikbud, 2014). Strategi yang bisa digunakan oleh guru dalam upaya meningkatkan kemampuan berpikir logis pada anak adalah dengan bernyanyi (Permatsari et al., 2019). Bernyanyi dapat membawa gelombang pikiran pada gelombang alpha dan beta (Mawikere et al., 2020). Dalam kondisi gelombang pikiran alpha, kondisi pikiran menjadi lebih relaks dan tenang, sedangkan ketika gelombang beta, suasana pikiran akan siap untuk berpikir. Dikarenakan hal tersebut, maka melalui bernyanyi diyakini dapat meningkatkan perkembangan berpikir logis anak. Hal ini sejalan dengan yang disampaikan Ni Nyoman Seri, guru di TK Dwijendra Mataram, yang mengatakan bahwa dalam belajar anak lebih senang jika diajak bernyanyi. Banyak ajaran agama yang diajarkan melalui bernyanyi dan para siswa menjadi lebih cepat hafal.

Bernyanyi pada siswa TK bukan hanya mengenai seberapa cepat siswa hafal lirik dari lagu, tetapi tentang kemampuan siswa memahami makna yang tertuang dalam lagu. Berkaitan dengan hal ini, setiap siswa memiliki kemampuan yang berbedabeda. Demikian halnya dengan perkembangan berpikir simbolik pada siswa. Pada anak usia 4-5 tahun, berpikir simbolik terwujud dalam: (1) menyebut banyak benda; (2) mengenal konsep bilangan; (3) mengenal lambang bilangan; dan (4) mengenal lambang huruf. Sedangkan pada anak usia 5-6 tahun ditandai dengan: (1) mampu menyebutkan lambang bilangan 1-10; (2) menggunakan bilangan dalam menghitung; (3) mampu mencocokan bilang dengan lambangnya; (4) mengenal huruf, baik vocal maupun konsonan; merepresentasikan berbagai macam benda dalam bentuk gambar atau tulisan (mendikbud, 2014).

Berkaitan dengan perkembangan kemampuan berpikir simbolik anak, Ni Luh Putu Tirtawati 
menyampaikan bahwa hal ini berkaitan dengan pembelajaran membaca, menulis, dan berhitung (calistung). Akan tetapi di TK Dwijendra Mataram, calistung memang diajarkan, tetapi baru sebagai pengenalan kepada anak. Anak sama sekali tidak dibebankan untuk harus bisa membaca, menulis dan berhitung. Hal ini didukung data temuan peneliti dalam melakukan observasi, terlihat hanya ada beberapa anak (kelas B2) yang sudah bisa mengenal angka dan huruf, dan sebagian besar belum bisa mengingat dengan baik.

Kemampuan berpikir simbolik anak di TK Dwijendra masih tergolong rendah, hal ini dikarenakan pembelajaran masih cenderung berpusat pada guru. Sebagaimana pembelajaran yang berpusat pada guru ini biasanya akan membuat siswa tidak mengeluarkan upaya maksimalnya dalam belajar dan anak menjadi kurang aktif (Nursyamsiah et al., 2019). Untuk mengantisipasi hal tersebut, dan agar perkembangan kemampuan berpikir anak di TK Dwijendra Mataram meningkat, perlu diterapkan strategi pembelajaran dengan pendekatan Student Center Learning (pembelajaran yang berpusat pada siswa).

Pemberian reward bagi siswa yang mencapai perkembangan lebih cepat juga diharapkan akan semakin memotivasi siswa yang bersangkutan, disamping juga berupaya membangkitkan rasa "ingin mendapat reward"dari siswa yang lain. Dengan semakin banyaknya siswa yang termotivasi, bukan sebuah keniscayaan apabila perkembangan kognitif siswa akan mampu mencapai hasil BSB (Belajar Sangat Baik) atau BSH (Belajar Sesuai Harapan) bukan sebaliknya mendapat hasil BB (Belum Berkembang).

\section{d. Perkembangan Bahasa}

Bahasa merupakan sesuatu yang digunakan untuk berkomunikasi baik secara lisan maupun tulisan. Hal ini dikaitkan dengan kepentingan manusia untuk menyatakan isi pikiran, keinginan ataupun perasaan (Rina Devianty, 2017). Dalam konteks perkembangan anak, Bahasa menjadi aspek yang sangat penting, karena Bahasa menjadi kunci dalam melangsungkan Komunikasi. Perkembangan Bahasa pada anak mencakup pemahaman Bahasa, mengungkapkan Bahasa, dan keaksaraan. Dalam memahami Bahasa, ada beberapa aspek yang menjadi indikator, seperti menyimak perkataan orang lain, mengerti dua perintah secara bersamaan, mengerti cerita yang dibacakan, mengenal semakin banyak perbendaharaan kata, memahami sebuah aturan dalam permainan serta bersikap senang dan menghargai bacaan (Mendikbud, 2014).

Berkaitan dengan pengungkapan Bahasa, ada dua indikator yang bisa dijadikan acuan, yaitu mulai menyatakan keinginan dengan mengucapkan kalimat sederhana dan mulai menceritakan pengalaman yang dialami dalam cerita sederhana (Patiung et al., 2019). 
Sedangkan berkaitan dengan keaksaraan, berkorelasi dengan perkembangan kognitif, yaitu berpikir simbolik. Pada aspek ini anak juga lebih diupayakan mampu mengenali simbol-simbol huruf sebagai bagian dari keaksaraan.

Ni Wayan Sucitra menuturkan bahwa perkembangan Bahasa pada anak menjadi tantangan sendiri dalam pembelajaran. Hal ini disebabkan ada siswa yang ketika mulai bersekolah di TK Dwijendra Mataram, memang belum bisa berkomunikasi dengan baik. Ketika menemukan keadaan semacam ini strategi yang digunakan oleh seorang guru adalah berusaha seperti mengerti apa yang diucapkan siswa. Disini pula dituntut kemampuan guru dalam memahami gerak-gerik siswa, sehingga lebih mudah mengerti apa yang dimaksud. Guru harus lebih meningkatkan partisipasinya dalam pergaulan si anak, karena harus menjadi pendamping saat si anak berkomunikasi dengan temannya.

Hingga saat ini, sebagian besar siswa di TK Dwijendra Mataram sudah mampu berkomunikasi secara aktif dengan guru maupun dengan temannya. Untuk beberapa kasus anak yang lambat dalam perkembangan Bahasa, pihak sekolah menyarankan agar diimbangi dengan pemeriksaan dokter ataupun psikolog. Hal ini dimaksudkan agar para guru dan orang tua bisa memberikan stimulus yang tepat ke depannya bagi perkembangan si anak.
Perkembangan Bahasa pada anak akan sangat memberikan pengaruh pada perkembangan kognitif anak, dan hal yang menjadi perhatian berkaitan dengan perkembangan Bahasa anak selain peran guru di TK/PAUD adalah berkaitan dengan pengetahuan yang dimiliki oleh orang tua, dan pola asuh yang digunakan oleh orang tua dalam mendidik anak (Safitri, 2017).

\section{e. Perkembangan Sosial-Emosional}

Perkembangan sosial-emosial sangat dipengaruhi oleh perlakuan dan bimbingan yang diberikan oleh orang tua kepada anak. Anak yang merasa aman di lingkungan keluarga akan memiliki perkembangan sosialemosional yang lebih baik daripada anak yang merasa tidak nyaman di lingkungan keluarga (Nurmalitasari, 2015).

Aspek yang perlu diperhatikan dalam perkembangan sosial-emosial anak adalah terkait kesadaran diri, rasa tanggung jawab untuk diri sendiri dan orang lain, serta perilaku proposial. Dalam pergaulan antar siswa di sekolah, Ni Ketut Seri menuturkan ada tiga jenis siswa, yaitu siswa intropert, aktif dan hiperaktif. Untuk siswa intropert, biasanya si anak akan mengalami kesulitan dalam bergaul dan merasa rendah diri, malu dan enggan bergaul dengan temannya. Untuk menghadapi siswa seperti ini, guru menerapkan strategi pendampingan. Pendampingan yang dimaksud, guru akan berusaha selalu mendampingi siswa hingga siswa 
tersebut merasa nyaman dan menemukan kenyamannya di sekolah.

Untuk kategori siswa yang kedua, yaitu siswa aktif, guru sangat berharap banyak siswa seperti ini. definisi siswa aktif disini adalah siswa yang bisa diajak berinteraksi dan memberikan timbal balik dalam pembelajaran. Hal ini tentunya akan memudahkan guru dalam melakukan evaluasi. Sedangkan untuk kategori siswa yang terakhir, yaitu siswa hiperaktif, ini memerlukan strategi guru yang lebih menantang daripada menghadapi siswa intropert. Di TK Dwijendra Mataram, setiap kelas memiliki siswa yang cenderung hiperaktif. Ni Wayan Sucitra menegaskan, bahwa untuk menghadapi siswa semacam ini guru tidak boleh melepaskan pantauan, hal ini dikarenakan siswa semacam ini kerapkali saking aktifnya malah merugikan orang-orang di sekitarnya. Yang dilakukan guru ketika mengdapai siswa semacam ini adalah dengan memeluk siswa hingga siswa tersebut merasa tenang, dan perhatiannya bisa fokus kembali. Namun apabila perilaku siswa tersebut sama sekali sulit dikendalikan, guru akan berkonsultasi dengan orang tua agar memberikan terapi pada si anak.

Hasil penelitian Mulyani (2017) menyebutkan bahwa cara lain yang bisa digunakan untuk meningkatkan perkembagan sosial-emosional anak adalah dengan membacakan cerita. Cerita yang dimaksud adalah cerita yang mampu membuat siswa terpukau, sehingga secara sosialemosional bisa terbawa dalam suasana cerita (Mulyani, 2017). Terlebih apabila dalam menerapkan metode bercerita didukung dengan media buku cerita yang berisi gambar, antusias siswa akan semakin meningkat (Luh et al., 2021). Namun seorang guru juga perlu memilah cerita yang cocok untuk diberikan kepada anak, upayakan agar cerita yang diberikan dapat memberikan sentuhan emosi positif bagi si anak, sehingga perkembangan sosial-emosionalnya menuju arah perkembangan yang positif.

\section{f. Perkembangan seni}

Ada sebuah ungkapan yang menyatakan bahwa dengan seni manusia dapat memberikan sentuhan kehalusan pada kehidupannya. Seni selalu identic dengan keindahan, keharmonisan, kedamaian, keanggunan, dan daya memikat hati. Inti dari seni adalah menciptakan segala sesuatu yang menyenangkan (mengandung unsur keindahan) (Asy'ari, 2007). TK Dwijendra Mataram, sebagai salah satu TK berbasis hindu juga menempatkan seni sebagai bagian holistik dari aktivitas pembelajarannya.

Perkembangan seni pada anak dikategorikan menjadi dua, yaitu anak mampu menikmati berbagai alunan lagu atau suara dan tertarik dengan kegiatan seni. Pada kategori pertama, kemampuan minimal yang menjadi indikator adalah seorang anak senang mendengarkan berbagai macam music atau lagu, sedangkan pada kemampuan maksimal seorang anak 
mampu memainkan alat musik. Selanjutnya pada kategori kedua, kemampuan minimal yang menjadi indikator adalah anak mampu memilih lagu yang disukai, sedangkan kemampuan maksimalnya adalah mampu membuat sebuah karya seperti bentuk sesungguhnya (miniatur) (Mendikbud, 2014).

Ni Wayan Sucitra menuturkan bahwa dalam upaya pengembangan seni siswa TK Dwijendra Mataram, pihak sekolah memberikan pelatihan menari, drum band, dan yoga asanas kepada siswa. Pelatihan menari dan drum band sudah jelas merupakan pengembangan seni, sementara untuk latihan yoga asanas melatih daya seni melalui latihan olah tubuh dan yoga art, melalui acro yoga (Windariyanti et al, 2021). Dengan memberikan pelatihan dalam kegiatan ekstra kurikuler tersebut, siswa dapat memilih kegiatan yang disukai sesuai minatnya. Sehingga terlihat sekali penerapan teori humanism dalam tata kelola TK Dwijendra Mataram.

Seni sangat berkaitan dengan kreativitas. Kreativitas akan semakin lahir apabila mampi mengembangkan bakat seni yang dimiliki. Kreativitas merupakan segala upaya untuk menciptakan sesuatu sesuai dengan kemampuan imajinasi (Astuti, 2013). Jadi orang seni adalah orang yang mampu berimajinasi dengan baik. Sehingga dengan perkembangan seni pada anak, anak juga akan memiliki kemampuan imajinasi semakin baik yang berdampak pada daya kreativitas si anak. Disamping itu, pengembangan kreativitas seni yang optimal akan menunjang terbentuknya karakter mulia pada anak (Sari et al., 2021). Demikian pula halnya dengan pembelajaran di TK Dwijendra Mataram, perkembangan seni anak yang dilatih melalui kegiatan ekstra kurikuler diharapkan mampu membangkitkan kreativitasnya selain sebagai upaya agar siswa mulai mampu mengenali minat dan bakatnya dan menjadi pondasi bagi pengembangan karakter mulia.

\section{SIMPULAN}

Keberhasilan

proses pendidikan di Taman Kanak-Kanak (PAUD) bisa dilihat dari pencapaian perkembangan anak. Pencapaian perkembangan anak yang dimaksud mencakup perkembangan nilai agama dan moral, perkembangan fisikmotorik, perkembangan kognitif, perkembangan Bahasa, perkembangan sosial-emosional dan perkembangan seni. Di TK Dwijendra Mataram, perkembangan anak menjadi perhatian yang diupayakan agar dapat tercapai secara maksimal. Usia pra sekolah, termasuk pada saat menempuh pendidikan di TK, merupakan usia emas bagi perkembangan anak. Ketika pada usia ini anak bisa dikembangkan dengan maksimal, maka pada usia-usia selanjutnya anak akan dapat berkembang dengan baik pula. Guna mencapai perkembangan anak yang optimal, guru sebagai orang tua siswa di TK Dwijendra Mataram memiliki strategi sebagai langkah-langkah 
sistematis dan terkontrol. Dalam upaya mengoptimalkan perkembangan nilai agama dan moral guru di TK Dwijendra Mataram menggunakan strategi pembiasaan untuk menumbuhkan budaya beragama dan bermoral. Selanjutnya pada aspek fisik-motorik guru menggunakan strategi interaktif learning dan pastisipatif learning. Pada aspek kognitif, guru menggunakan strategi pemberikan Reward, metode bernyanyi dan pendekatan Student Center Learning.

Pada aspek Bahasa, guru menggunakan strategi pendampingan kepada siswa secara maksimal.

Kemudian pada aspek perkembangan sosial-emosional, strategi yang diterapkan adalah dengan metode bercerita yang memukau. Sedangkan untuk pengembangan aspek seni, sekolah mengadakan kegiatan ekstra kurikuler yang memberikan pilihan bagi siswa dalam mengembangkan potensi seninya.

\section{DAFTAR PUSTAKA}

Astuti, F. (2013). Menggali dan Mengembangkan Potensi Kreativitas Seni pada Anak Usia Dini. Komposisi: Jurnal Pendidikan Bahasa, Sastra, Dan Seni, 14(1). https://doi.org/10.24036/komp osisi.v14i1.3950

Asy'ari, M. (2007). Islam dan seni. HUNAFA: Jurnal Studia Islamika, 4(2), 169-174.

Chamidah, A. N. (2009). Deteksi dini gangguan pertumbuhan dan perkembangan anak. Jurnal pendidikan khusus, 5(2), 83-93.
Isnaini, A. (2014). Kekerasan atas nama agama. Kalam, 8(2), 213-228.

Khiyarusoleh, U. (2016). Konsep Dasar Perkembangan Kognitif Pada Anak Menurut Jean Piaget. DIALEKTIKA Jurnal Pemikiran Dan Penelitian Pendidikan Dasar, 5(1).

Yuni Astiti, N. L., Rasmini, N. W., \& Drajati Ekaningtyas, N. L. (2021). PENGARUH PENGGUNAAN METODE BERCERITA TERHADAP PENINGKATAN KEMAMPUAN MENYIMAK ANAK USIA DINI. Kumarottama: Jurnal Pendidikan Anak Usia Dini, 1(1), 9-18. https://doi.org/https://doi.org /10.53977/kumarottama.v1i1.262 Mawikere, V. A. E., Raharjo, J., \& Budiarto, A. (2020). Analisis Sinyal Gelombang Otak Manusia Saat Bermain Gitar Sembari Bernyanyi Dan Tidak Bernyanyi Berbasis EEG Dengan Menggunakan Metode Discrete Wavelet Transform Dan KNearest Neighbor. eProceedings of Engineering, 7(2).

Mendikbud. (2014). Peraturan Menteri Pendidikan dan Kebudayaan Nomor 137 Tahun 2014 Tentang Standar Nasional Pendidikan Anak Usia Dini.

Mulyani, N. (2017). Upaya Meningkatkan Perkembangan Sosial Emosional Anak Usia Dini. Jurnal Ilmiah Mahasiswa Raushan Fikr, 3(1), 133-147. https://doi.org/10.24090/jimrf.v 3i1.1013

Nurmalitasari,

F.

(2015). Perkembangan Sosial Emosi pada Anak Usia Prasekolah. Buletin Psikologi, 23(2), 103. 
https://doi.org/10.22146/bpsi.1 0567

Nursyamsiah, H., Cendana, T. P., Rohaeti, E. E., \& Alam, S. K. (2019). Kemampuan Berpikir Simbolik Anak Usia Dini Pada Usia 5 - 6 Tahun. CERIA (Cerdas Energik Responsif Inovatif Adaptif), 2(6),

286.

https://doi.org/10.22460/ceria.v 2i6.p286-294

Patiung, D., Ismawati, I., Herawati, H., \& Ramadani, S. (2019). Pencapaian Pada Aspek Perkembangan Anak Usia 3-4 Tahun Berdasarkan Standar Nasional Pendidikan Anak Usia Dini. NANAEKE: Indonesian Journal of Early Childhood Education, 2(1), 25. https://doi.org/10.24252/nanan eke.v2i1.9223

Permatsari, D., Rohaeti, E. E., \& Westhisi, S. M. (2019). Meningkatkan Kemampuan Berpikir Logis Anak Usia Dini Melalui Metode Bernyanyi Pada Anak Kelompok B. CERIA (Cerdas Energik Responsif Inovatif Adaptif), 2(5), 230. https://doi.org/10.22460/ceria.v 2i5.p230-236

Rina Devianty. (2017). Bahasa Sebagai Cermin Kebudayaan. Jurnal Tarbiyah, 24(2), 226-245.

Rozalena, R., \& Kristiawan, M. (2017). Pengelolaan Pembelajaran Paud Dalam Mengembangkan Potensi Anak Usia Dini. JMKSP (Jurnal Manajemen, Kepemimpinan, Dan Supervisi Pendidikan), 2(1), 76-86. https://doi.org/10.31851/jmksp. v2i1.1155

Rudiarta, I. W. (2021). Giatkan Pasraman dengan Pendekatan TTM. In I. K. P. Suardana (Ed.), Pasraman Era Kekinian (1st ed., pp. 321-335). CV. Global Aksara Pers.

Rudiarta, I. W. (2021). PENANAMAN NILAI PENDIDIKAN AGAMA HINDU MELALUI PENGABDIAN KEPADA MASYARAKAT DI PASRAMAN AMERTHA SANJIWANI RINCUNG. SELAPARANG Jurnal Pengabdian Masyarakat Berkemajuan, 5(1), 948-956.

Rudiarta, I. W., \& Pramana, I. B. K. Y. (2021, October). Mengembangkan Pembelajaran Paikem di Pasraman dalam Menyongsong Era Society 5.0. In Prosiding Seminar Nasional Pascasarjana (pp. 85-96).

Safitri, Y. (2017). Faktor-Faktor yang Berhubungan dengan Perkembangan Bahasa Balita di UPTD Kesehatan Baserah Tahun 2016. Jurnal Obsesi: Jurnal Pendidikan Anak Usia Dini, 1(2), 148.

https://doi.org/10.31004/obsesi. v1i2.35

Sari, E., Dyatmika, G. E., \& Dewi, N. P. (2021). STRATEGI GURU AGAMA HINDU DALAM MEMPERTAHANKAN MINAT BELAJAR EKSTRAKURIKULER TARI PADA SISWA. Padma Sari: Jurnal Ilmu Pendidikan, 1(01), 1018.

https://doi.org/https://doi.org /10.53977/ps.v1i01.314

Solihin RDM, Anwar Faisal, S. D. (2013). Kaitan antara status gizi, perkembangan kognitif, dan perkembangan motorik pada anak usia prasekolah. Penelitian Gizi Dan Makanan, 36(1), 62-72.

Sriwahyuni, E., Asvio, N., \& Nofialdi, N. (2017). Metode Pembelajaran Yang Digunakan Paud (Pendidikan Anak Usia Dini) 
Permata Bunda. ThufuLA: Jurnal Inovasi Pendidikan Guru Raudhatul Athfal, 4(1), 44. https://doi.org/10.21043/thuful a.v4i1.2010

Sulaiman, U., Ardianti, N., \& Selviana, S. (2019). Tingkat Pencapaian Pada Aspek Perkembangan Anak Usia Dini 5-6 Tahun Berdasarkan Strandar Nasional Pendidikan Anak Usia Dini. NANAEKE: Indonesian Journal of Early Childhood Education, 2(1), 52. https://doi.org/10.24252/nanan eke.v2i1.9385

Susanti, M. M., \& Trianingsih, Y. (2017). Efektivitas Terapi Bermain Play Dough Dan Puzzle Terhadap Tingkat Perkembangan Motorik Halus Pada Anak Usia Dini Di Paud Dahlia Godong. The Shine Cahaya Dunia Ners Jurnal, 2(1), 1728.

Suseni, M., Arini, N. M., \& Sasmika Dewi, N. P. (2021). IMPLEMENTASI METODE KOLASE DALAM MENINGKATKAN MOTORIK HALUS ANAK USIA DINI. Kumarottama: Jurnal Pendidikan Anak Usia Dini, 1(1), 1-8. https://doi.org/https://doi.org /10.53977/ kumarottama.v1i1.264

Wadu, L. B., \& Jaisa, Y. (2017). Pembinaan Moral Untuk Memantapkan Watak Kewarganegaraan Siswa Sekolah Dasar Kelas Tinggi. Jurnal Moral Kemasyarakatan, 2(2), 131-139.

Windariyanti, W., Wijana, I. N., \& Listiawati, N. P. (2021). PEMBELAJARAN YOGA DALAM PEMBENTUKAN KARAKTER SISWA DI PASRAMAN SAMIAGA MATARAM. Padma Sari: Jurnal Ilmu Pendidikan, 1(01), 19-27. https://doi.org/https://doi.org /10.53977/ps.v1i01.347 